\title{
The Larval Stages of Processa canaliculata Leach*
}

\author{
By
}

Robert Gurney, M.A., F.L.S.

With Figures 1-9 in the Text.

THE material upon which the following account of the development of $P$. canaliculata is based was mainly obtained in 1902 when working in the Laboratory at Plymouth. The larvæ were first noticed, and their identity suspected, in April of that year, and identification was made certain by keeping the larvæ in the "mysis" stage until they moulted into the post-larval form, some individuals being kept also through several subsequent moults. The intermediate stages were all taken from the plankton, since I was unable to hatch the larvæ from the egg. The only egg-bearing female seen at that time was taken on the Eddystone Ground on April 29, and her eggs were so far advanced that, although she was unfortunately killed, a few larvæ escaped from the eggs and made it possible to obtain some idea of the structure of the first zoæa.

During a short stay in Plymouth during April, 1922, I was able not only to pick out a few more specimens from the plankton then brought in, but also, by working through a large number of preserved plankton samples, to obtain a considerable amount of additional material, mainly of later stages. A few specimens have also been found in samples of plankton from the North Sea preserved at the Fisheries Laboratory at Lowestoft, for the loan of which I am indebted to Mr. A. C. Hardy. But the larvæ of this species are much rarer in the North Sea than in the neighbourhood of Plymouth, where they are quite common.

Several females with eggs were brought in during my visit in 1922, but unfortunately the eggs were in all cases in early stages and the attempt to keep them till they hatched failed. I was, however, fortunate in finding in the plankton one zoæa in the first stage, so that the series from hatching to the adult is complete.

The breeding period evidently begins very early. Egg-bearing females have been taken at Plymouth in February, and advanced larvæ occur

* Leach's name was published on July 1, 1815, in Part IV of his Malacostraca Podophthalmata Britanniæ. Processa canaliculata must, therefore, be used in place of Nika edulis Risso, 1816. 
in the plankton early in April, and continue throughout the summer. Advanced larvæ only are taken in September. Risso states (1816) that the eggs are laid several times in the year, and so extended a breeding period points to the production of several broods.

$P$. canaliculata is a species of extraordinarily wide distribution and has a vertical range from between tide marks to 326 fathoms. According to Kemp it is found all round the English and Scottish coasts, but appears to be mainly a southern form.

My own experience of it is very limited, but Dr. J. H. Orton has been kind enough to give me information as to its occurrence in the Plymouth area. It is found in Plymouth Sound occasionally in very small numbers, and has even been taken on the shore, but it is not uncommon in the deeper water of the Rame Head and Eddystone Grounds in 20-30 fathoms, either on mud or on sand.

Specimens kept in aquaria and provided with stones were always found quiescent during the day, wedged in between the stones, so that it is possible that it may be common on rocky grounds where, however, its presence would with difficulty be ascertained. It shows no inclination to burrow in sand.

The colour changes of this species are rather striking, and Jourdain (1878) has described experiments on this change of colour. In sunlight the animal was found to be transparent, slightly tinged with brown, but to become red in the dark. Light had, therefore, the effect of causing contraction of the pigment in the chromatophores.

Two specimens were kept under observation in 1902. These were both of a dirty white colour when brought up in the trawl, but both, in a subdued light, became later of a flesh-pink colour, which was retained, except when in a strong light. One of the specimens which was kept in the dark for some hours became quite red, but when taken out and placed in strong light became white in nine minutes, the antennæ retaining the pink colour longest.

In April, 1922, I had the opportunity of watching several specimens. Some of these were kept on shelly sand, and these varied little in colour, being of a pale rose-red during the day and a little redder at night.

On the other hand, a specimen brought in from the Sound, and kept among rocks, was of a greenish colour when taken, and remained so for four days. It then became a brilliant red at night, reverting to green in the daytime. From that time till I left Plymouth the same change occurred regularly, the brilliant red of its nocturnal colouring being very striking. Risso describes the colour as "rouge incarnat," but with yellow spots ; while Cuvier also figured it (1829) a vivid red. Dr. Orton informs me that the colour is always red when the animal is brought up 
from deep water. This is probably the normal colour under natural conditions, and the changes observed in the Laboratory are merely due to abnormal lighting.

So far as I am aware the only published reference to the larva of Processa is that of Czerniavsky (1884), who mentions a larva of $6 \mathrm{~mm}$. in length, but without giving much information concerning it. He seems to have had before him a specimen either in the last larval or first postlarval state.

As will be seen from the following account, the zoæae of Processa are so like those of Pandalus and Spirontocaris that the recognition of the early stages is by no means easy, and the development further resembles that of Pandalus in the number of moults passed through, and the gradual attainment of the adult form. Sars has distinguished eight or nine larval stages in the development of Pandalus boreatis, and the same number is found in Pandalina brevirostris; while in the Crangonidæ, and also commonly in the Palæmonidæ there are only five stages corresponding to the same number of moults. In Processa I have found the separation of the larvæ into distinct stages of development a matter of extreme difficulty. When working through my original material it seemed that eight stages could be distinguished, though only by small differences; but examination of increased material has shown that individual variation is so great that the distinctions between the stages, both in respect of size and also of development of appendages, almost disappear. I now, however, recognise nine stages which will be defined below, but it must be admitted that, after Stage III, the series is practically continuous. It does not necessarily follow, and I also think it improbable, that any one individual will pass through each of these stages. Sollaud (1912) has stated that the number of moults in the development of Palæmonetes varies to some extent with the conditions of life, and I have myself found that Palæmonetes larvæ kept under the rather adverse conditions of aquarium culture may moult repeatedly without material structural changes. It is probable that in Processa and also in Pandalus some of the "stages" may be omitted by more vigorous individuals, while they may be even more numerous in others. For example, on the one hand Stage VIII may certainly moult direct to the post-larval condition and, on the other hand, I have included in Stage V a number of larvæ which are not of equal age, indicating that this stage may represent more than one moult.

In Caridean development the first two moults seem invariably to produce larvæ of exactly the same general structure, so that Stages II and III are precisely comparable throughout, while from this stage onwards development may proceed as in Processa by progressive small changes. It is only in certain groups such as the Crangonidæ that larval 
development is compressed within five stages, separated by important structural differences.

In Pandalina brevirostris the development from hatching to the postlarval state takes, under laboratory conditions, about two months, ${ }^{*}$ which is considerably longer than that of Leander, in which a moult takes place at intervals of about eight days, and development is complete in about four weeks (Mortensen, 1897). It seems likely, therefore, that moults occur in Pandalus and Processa at about the same intervals, so that the duration of larval life is increased. The difficulty of keeping these larvæ alive for any length of time makes it impossible to attain to any certainty in a matter of this kind.

I am indebted to Miss Lebour for records of the moults of a specimen reared by her in a plunger jar at Plymouth. This specimen was in Stage VIII when first put in the jar and moulted as follows :-

\begin{tabular}{|c|c|c|c|c|c|c|}
\hline \multirow{2}{*}{\multicolumn{2}{|c|}{$\begin{array}{l}\text { To Stage IX } \\
\text { To 1st Post-larval }\end{array}$}} & & & & April 3 & 3,1922 \\
\hline & & & & & April 12 & 2 \\
\hline To 2nd & , & & 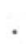 & & April 22 & \\
\hline To 3rd & , & & ${ }^{\circ}$ & . & May 1 & 1 \\
\hline To 4th & , & & . & . & May & 8 \\
\hline
\end{tabular}

Stage I. Length, 1.9 to $2 \cdot 2 \mathrm{~mm}$.

The general form closely resembles that of Pandalina brevirostris, but the rostrum is apparently absent and the fifth abdominal segment bears in this, and in all succeeding stages, a pair of small dorsal spines. The presence of these spines suffices to distinguish the larva at any stage from that of Pandalina, but similar spines have been seen in larvæ apparently belonging to some species of Hippolytidæ (e.g. Spirontocaris cranchii). A pair of spines is present on this segment in late larvæ of Pandalus bonnieri, and (according to Sars) in P. montagui, but they are absent in the first zoæa of the latter. $P$. borealis resembles Processa in having them at all stages.

The ventral margin of the shell ends anteriorly in a strong spine behind which there are two small denticles. These denticles increase in number in later stages and are retained until the post-larval stage.

The telson is triangular and much less deeply cleft than in Pandalus. The outermost seta is inserted nearly half-way up the side, and both it and the next seta are ciliated on the inner side only.

The first antenna is long and slender, the first joint bearing a long ciliated seta, and the second a ciliated seta and three æsthetes.

The second antenna has a scale bearing two setæ on the outer side as

\footnotetext{
* Larvæ of the species were reared from hatching to the post-larval state in 1903 in a "plunger jar" in the Plymouth Laboratory.
} 
in Pandalus and Hippolyte, and ten inner and terminal setæ (see Fig. 2, A). The outer setæ are much longer than in Hippolyte varians. There is no trace of segmentation of the end of the scale, a striking difference between this species and the larvæ of both Pandalidæ and Hippolytidæ so far as is known. The endopodite is a tapering spine

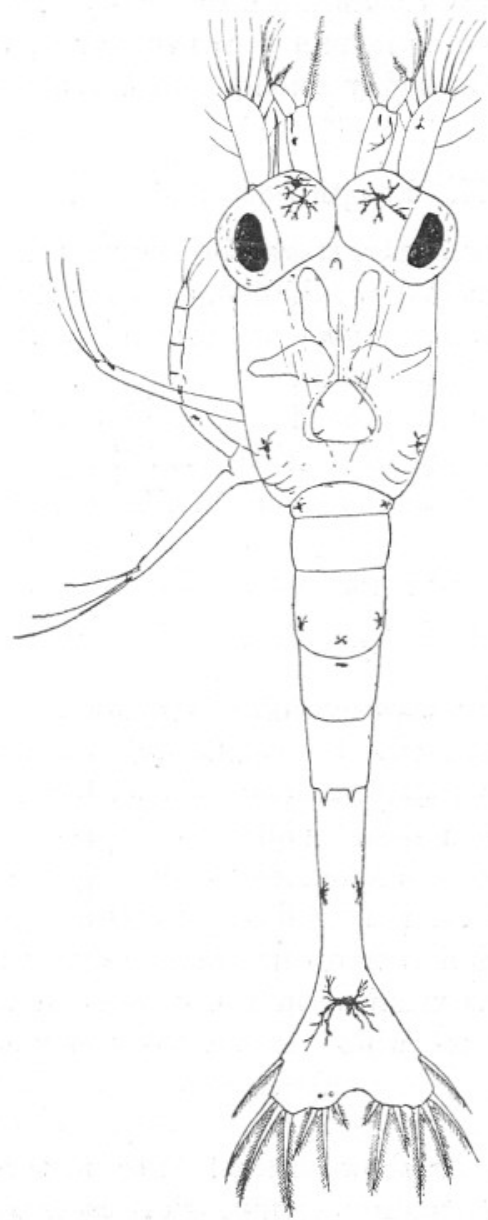

Fig. 1.-Stage I, showing the arrangement of the Chromatophores.

scarcely more than half the length of the scale. In Pandalus this branch bears two setæ.

The three pairs of maxillipedes are present as biramous swimming legs, while the rudiments of the first two pairs of pereiopods are visible. The exopodites of the maxillipedes bear respectively 4, 5, 5 setæ.

As has been said above, I have seen larvæ which were liberated from the 
egg on killing of the parent. Though larvæ in later stages have been found in abundance in the plankton, I have only on one occasion recognised a larva in the first stage. This one was taken on 22.4.22, and measured $1.95 \mathrm{~mm}$. The chromatophores are yellow or yellow and red, and their distribution is shown in Fig. 1.

The zoæa of Spirontocaris cranchii, which closely resembles that of Processa, may be recognised by its minute rostrum and jointed antennal scale. It is also much more highly coloured, with very numerous large chromatophores.

\section{Stage II. Length 1.85 to $2.9 \mathrm{~mm}$.}

I have seen several larvæ of this stage, the majority measuring about $2.3 \mathrm{~mm}$., but a single individual of $1.85 \mathrm{~mm}$. shows that there may be a great range in size. S. Kemp (1906) has drawn attention to the exceptional variation in size of the adult.

The rostrum is now present, though very small, and a pair of small supra-ocular spines have appeared. Just behind the rostrum is a small, rounded knob, and in later stages a second similar knob appears on the carapace towards its posterior end.*

The eyes are stalked, and the telson has gained an additional median pair of setæ. The second seta of the telson is ciliated on both sides.

The two pairs of antennæ scarcely differ from those of the first zoæa, but I should draw attention here to a small lobe which, in this and all later stages, is borne at the end of the stem. This lobe carries four small, feathered setæ with swollen bases similar to the sensory setæ which appear later at the base of the antennule in the region of the otocyst. The interest of this, which I shall call the "antennular lobe," lies in the fact that a precisely similar structure is found in the larvæ of most, if not all, Caridea, and is retained in many eases in the adult (e.g. Leander), while a structure which is obviously homologous occurs also in adult Euphausiacea (e.g. Nyctiphanes) and in most Mysidæ (e.g. Neomysis).

The mandibles (Fig. 2, C) show distinct differentiation into molar and cutting parts, and are slightly asymmetrical as regards the spines borne by them.

The first maxillæ are of the usual form, consisting of two basal lobes, the proximal one armed with five long, curved spines and the distal with a number of short, thick spines in two rows (Fig. 2, B). The palp is distinctly two-jointed, the proximal joint with two and the distal with three spinous setæ. The second basal lobe bears a seta on its outer side.

\footnotetext{
* The anterior knob corresponds to the "dorsal organ " referred to by Hansen in his "Studies on Arthropoda," 1921.
} 
It is possible that this seta, which is also found in Hippolyte (Sars) and in some Brachyura, may represent the setiferous lobe (exopodite?) of the first maxilla of Sergestidæ. It is not found in Leander, the Crangonidæ or Pandalidæ.

The second maxilla has a large palp or endopodite with three inner lobes (Fig. 4, A). The basal part of the appendage bears four distinct lobes, and apparently consists of two joints, each bearing two lobes or endites. There is, in most Caridea, a distinct division between the

A.
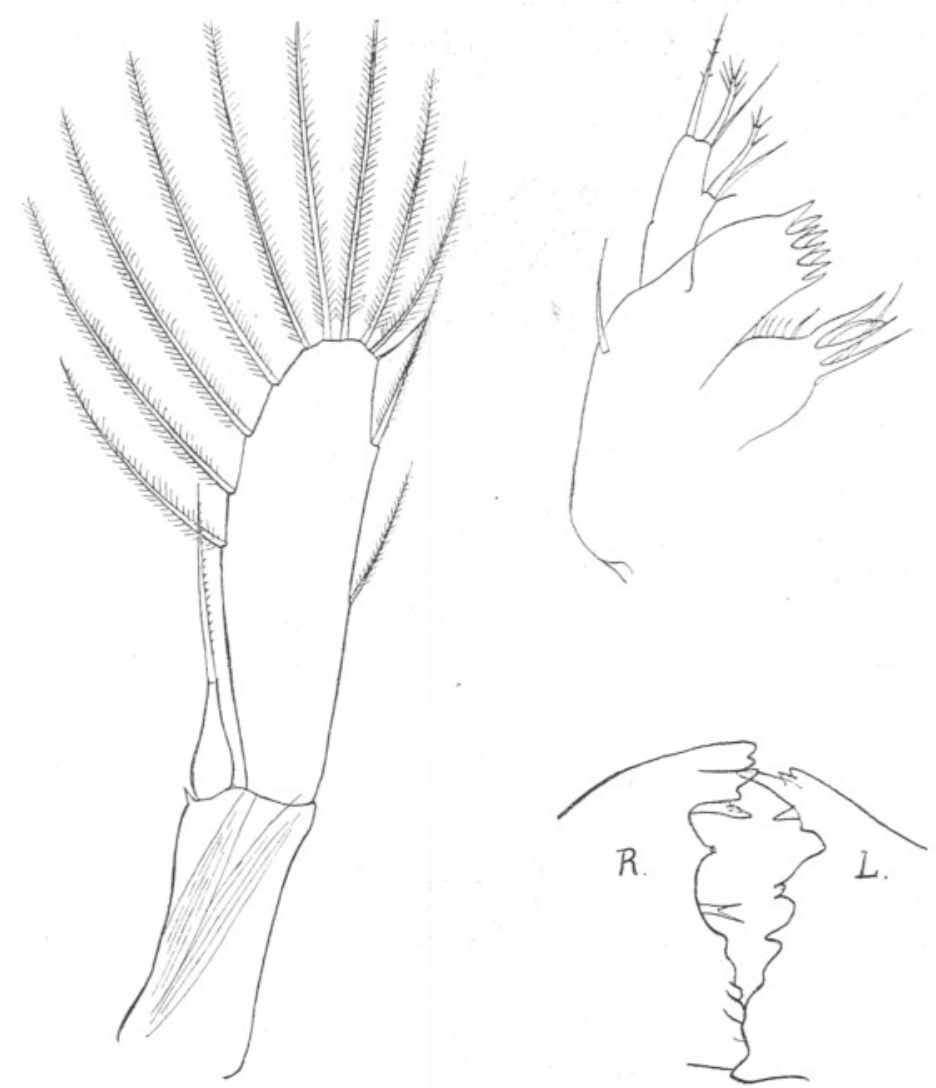

B.

FIG. 2.-Stage II.
A. 2nd Antenna.
B. Ist Maxilla.
C. Mandible.

regions bearing the basal and distal pairs of lobes, and it is quite clear that the palp and scaphognathite are endopodite and exopodite respectively springing from the second joint; but it is generally possible to distinguish a line of division running between the two basal 
lobes to an indentation of the outer edge, giving the appearance of three joints. On the other hand, this apparent line of division bears no relation to the muscles of the limb, and I am of opinion that it does not really indicate a three-jointed stem.

The first pair of pereiopods is developed as a swimming limb with a five-jointed endopodite nearly equal in length to the exopodite. The ischio-meral joint in this and in the maxillipedes is indistinct at this stage. The exopodites bear 5, 5,6,6 setæ respectively. The last four pairs of pereiopods are visible as buds, those of the second pair being bilobed and larger than the others.

The first maxillipede bears a minute rudiment of the epipodite, but there is no trace of gills.

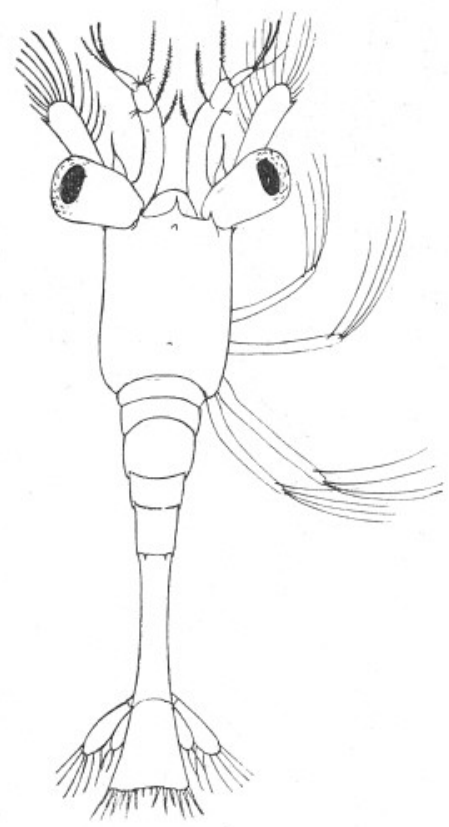

FIG. 3.-Stage III.

Stage III. Length 2.53 to $2.65 \mathrm{~mm}$.

The general form of the body in this and succeeding stages remains the same, the carapace broad and parallel-sided, with a minute rostrum not reaching to the end of the frontal lobe, and a pair of supra-ocular spines. The telson is still triangular in shape, but somewhat more elongated in proportion to its width, and bears fourteen terminal spines, the outermost spine of Stage II having been lost.

The first antenna has a two-jointed stem which is greatly curved and 
shows a faint trace of separation of the first joint into two. This joint bears two inner setæ only. The inner branch is in the form of a minute knob bearing a seta, and the outer branch bears one ciliated seta and three æsthetes. These æsthetes are easily broken off, but it will probably be found that three is the normal number for all Caridea in this and earlier stages.

The second antenna differs from preceding stages in the reduction or loss of the two outer setæ on the scale, and the presence of an outer terminal spine. The scale is markedly wider distally and retains thls character in later stages. The flagellum has still the form of a smali knob terminating in a spine.

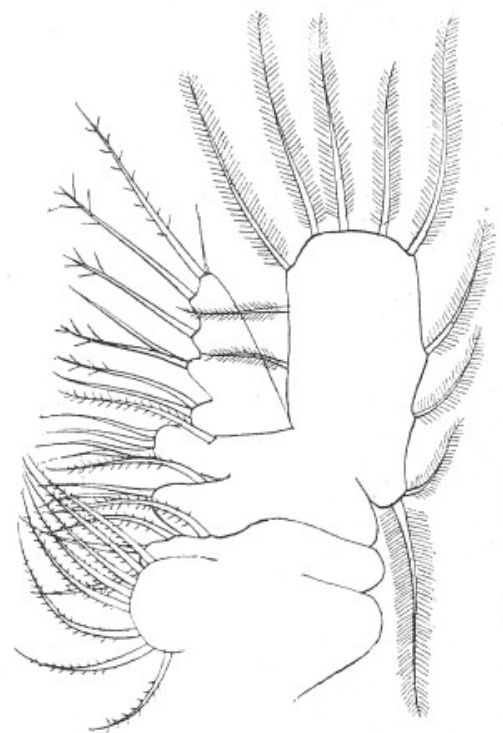

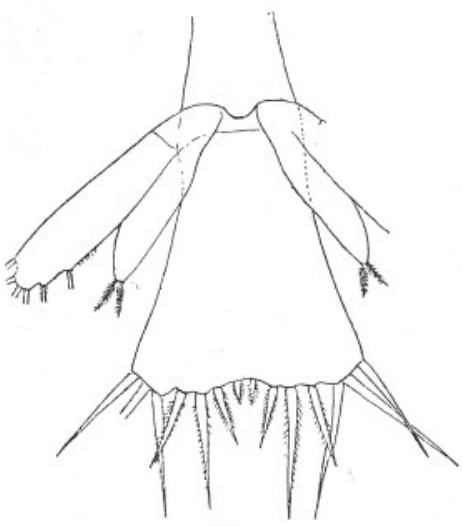

B.

A.

Frg. 4.- Stage III.

A. 2nd maxilla.

B. Telson and uropods from below.

The mouth parts show no important change, except that the seta which is present on the outer side of the second basal lobe of the first maxilla appears to be lost.

The first and second pereiopods are now biramous swimming limbs with long five-jointed endopodites.

The first maxillipede has a small epipodite, but I have not been able to see any trace of gills.

The pleopods are not visible, but the uropods are developed, the outer branch with six setæ and the inner with two small terminal setæ (Fig. 4, B). There is no ventral spine at the end of the sixth abdominal segment. 
Stage IV. Length $2.8 \mathrm{~mm}$.

The chief differences between this and Stage III are :-

1. The first antenna has two additional inner setæ on the first joint.

2. The flagellum of the second antenna has lost its terminal spine and is now a short rod without setæ.

3. The epipodite of the first maxillipede is larger.

4. The third pereiopod is now fully developed.

5 . There are rudiments of three pairs of pleurobranchs corresponding to the first three pereiopods (Fig. 5).

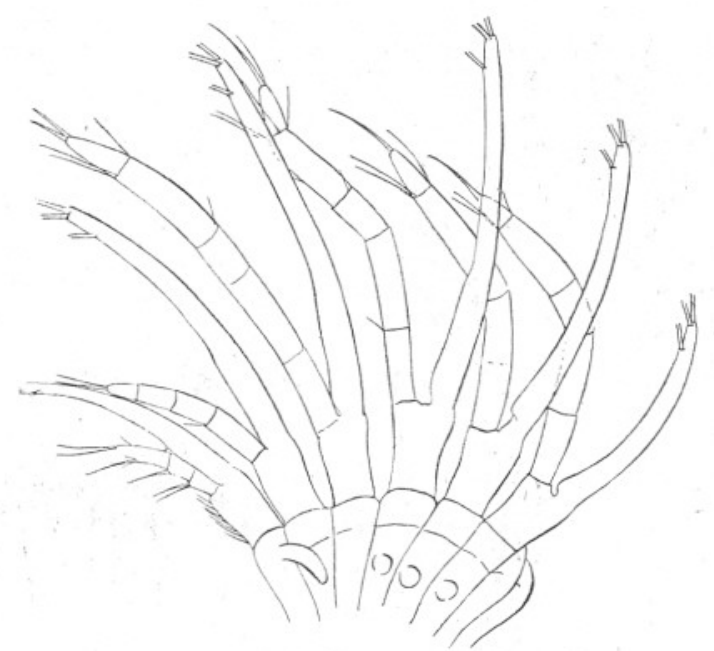

FIG 5.-Stage IV, thoracic appendages, showing rudiments of pleurobranchs.

6. The telson is somewhat narrower distally, being nearly twice as long as broad, and there is a ventral spine at the end of the sixth abdominal segment. The outermost seta of Stage III is situated about half-way up the outer edge of the telson, while the second seta is reduced to a small hair on the outer angle.

7. The uropods have several setæ on each branch.

\section{Stage V. Length 3.95 to $4.8 \mathrm{~mm}$.}

There is considerable variation among the specimens of this stage, indicating that the larvæ are not all of the same age. Probably there are in some cases intermediate moults; with the result that some larvæ unite the characters of Stages IV and V, and others those of V and VI. 
But there is no doubt that a definite advance from Stage 4 can be thus defined :-

1. First antenna. Exopodite with two or three bundles of æsthetes. Endopodite sometimes two-jointed.

2. Second antenna. Endopodite two-jointed, nearly half as long as the scale.

3. Pereiopods one to four developed, biramous. The fifth usually a long unjointed rod, bent forwards and without setæ. In some cases it is fully formed.

4. Pleopods present as small buds which are simple or, in some cases, bilobed.

5. Telson narrow and parallel-sided, the proportion of width to length being from $1: 2$ up to $1: 2 \cdot 75$.

6. All five pleurobranchs present. Epipodite on second maxillipede.

Stage VI. Length 3.85 to $5 \cdot 38 \mathrm{~mm}$.

This stage may be defined as follows :-

1. Second antenna. Flagellum from two-thirds to the whole length of the scale.

2. Fifth pereiopod fully developed and very long, reaching as far forwards as the eye, the carpus slightly expanded. In the first two pairs of legs there is a slight prolongation of the propodite--the first indication of the chelæ.

3. Pleopods developed as short-curved bilobed rods.

4. Telson narrow, the width less than one-third of the length.

5. Rostrum extending beyond the frontal lobe and down-curved. The smallest specimen of this stage seen-3.85 $\mathrm{mm}$.- -was exceptional in having the fifth leg fully developed, but no trace of pleopods.

\section{Stage VII. Length $6 \cdot 3 \mathrm{~mm}$.}

This is an ill-defined stage, differing little from Stages VI and VIIJ as follows:-

1. Second antenna. Flagellum a little longer than the scale.

2. First two pairs of legs subchelate.

3. Pleopods larger than in Stage VI, but without setæ. 


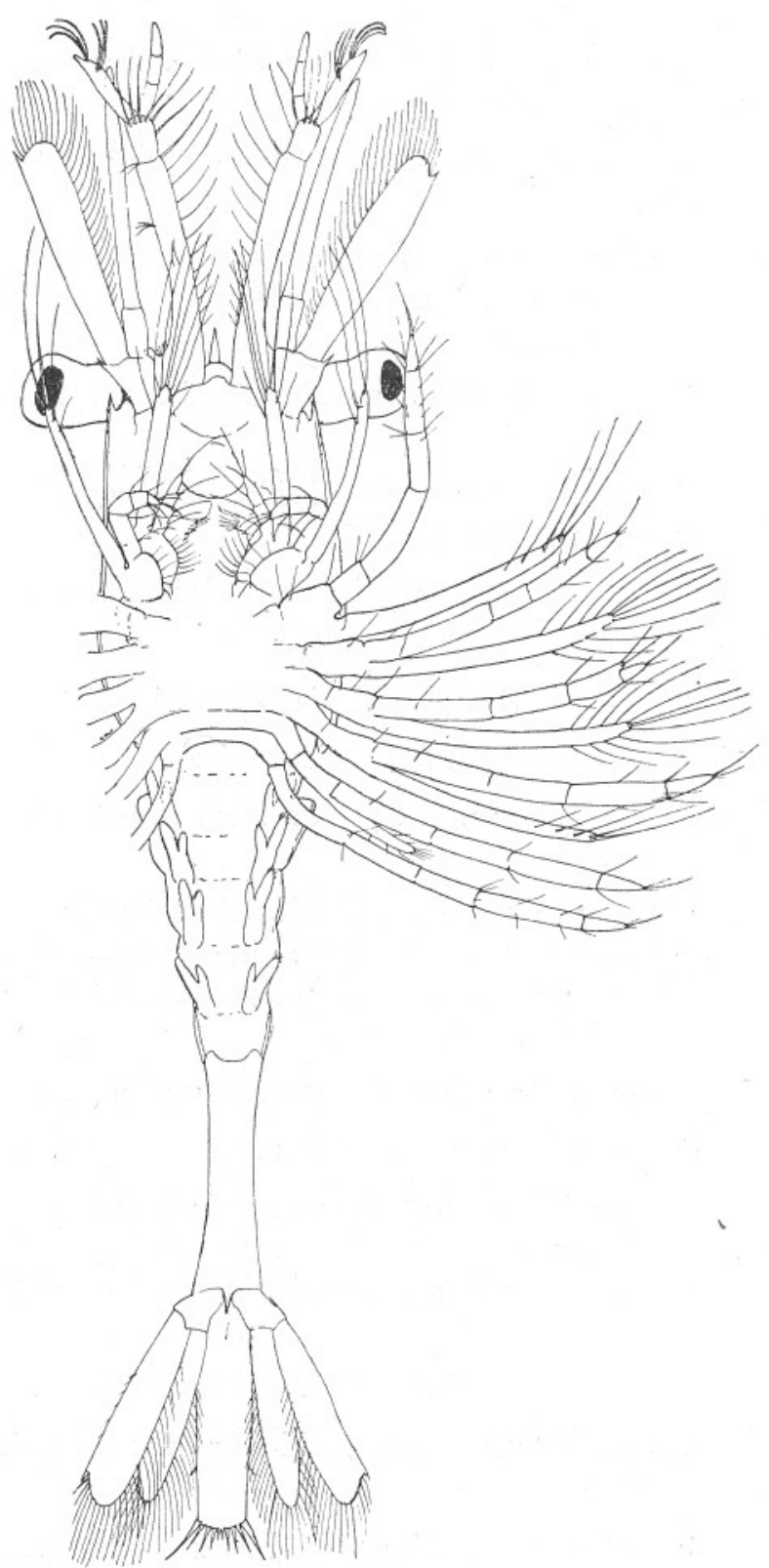

FIG. 6.-Stage VII, ventral view. 
Stage VIII. Length $5 \cdot 7$ to $7 \cdot 2 \mathrm{~mm}$.

This and the next stage also differ little from each other, but do undoubtedly represent distinct moults. In some cases, but apparently rarely, the larva moults directly from Stage VIII to the post-larval form, but as a rule the moult leads only to the slightly modified form of Stage VIII. This can not only be proved by examination of preserved specimens nearly ready to moult, but also by direct observation. Miss

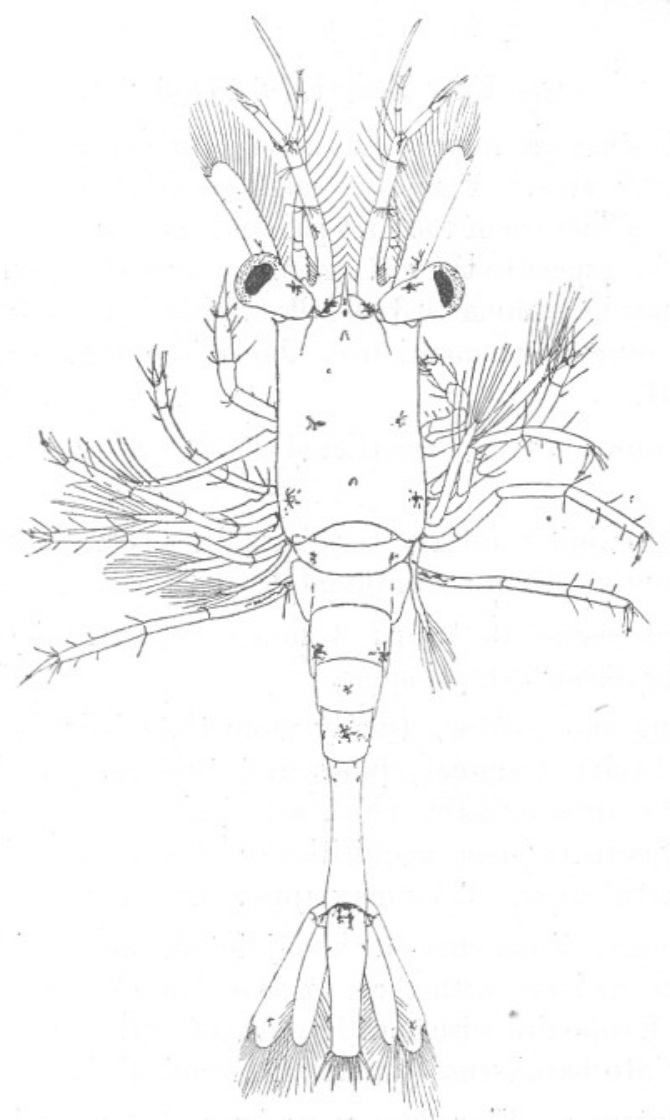

FIG. 7.-Stage VIII, dorsal view, showing arrangement of chromatophores.

Lebour has been good enough to give me the moulted skins of a larva reared by her in the Plymouth Laboratory, and I find that the first cast skin was of this stage and the second of my Stage IX.

Stage VIII has the following characters :-

1. Second antenna. The flagellum now greatly exceeds the length of the scale and may be jointed.

NEW SERIES, - VOL. XIII. NO. 1. DECEMBER, 1923. 
2. The first leg is short and stout, and chelate on the right side, but the chela is not quite fully developed and retains the larval spines.

3 . In the second leg the prolongation of the propodite is scarcely more than half the length of the Dactylus.

4. Pleopods large, biramous, but without setæ.

It is worth noting that the smallest specimen, measuring $(5 \cdot 7 \mathrm{~mm}$.), was about to moult to post-larval, while others of $7 \cdot 7 \mathrm{~mm}$. were preparing to moult to Stage IX.

\section{Stage IX. Length $7 \cdot 5$ to $9.5 \mathrm{~mm}$.}

Larvæ of this stage are conspicuous and not uncommon in the plankton of the Plymouth area. They are easily recognised as belonging to Processa by the structure of the first pair of legs, but they also approach the adult form in respect to the rostrum and other details. The characters of this larva may be summarised as follows, but it must be remembered that with the exceptions mentioned above it shares these characters with Stage VIII.

1. Rostrum down-curved, constricted at the end where it bears two setæ.

2. Carapace retaining anterior, and usually posterior, median knobs and traces of ventral anterior marginal denticles.

3. Abdominal segments 1 and 2 much expanded laterally. Sixth segment with posterior ventral spine.

4. Telson long and narrow, usually more than four times as long as broad; with twelve terminal spines and two pairs of lateraI spines (Fig 8, B). The anterior pair, which are situated rather on the dorsal surface, are apparently new acquisitions not corresponding to one of the original larval pairs. They may appear first in Stage VI.

5. First antenna. Stem curved, three-jointed, the first joint expanded and notched at the base, with three or four "otic" setæ on the margin of the notch. Exopodite with four bundles of æsthetes and first sign of differentiation into basal sensory part and terminal flagellum.

6. Second antenna. Flagellum very long $-3.2 \mathrm{~mm}$. in a specimen $8.75 \mathrm{~mm}$. long.

7. Mandibles still of larval form with distinct cutting and molar portions (Fig. 9, B).

8. Maxillipedes and maxillæ retaining larval form, with exception that the third maxillipede is very large and strong, as in the adult.

9. Legs 1 to 4 with well-developed exopodites, but these are much shorter than the endopodites. Leg 1 short and thick, simple on the 


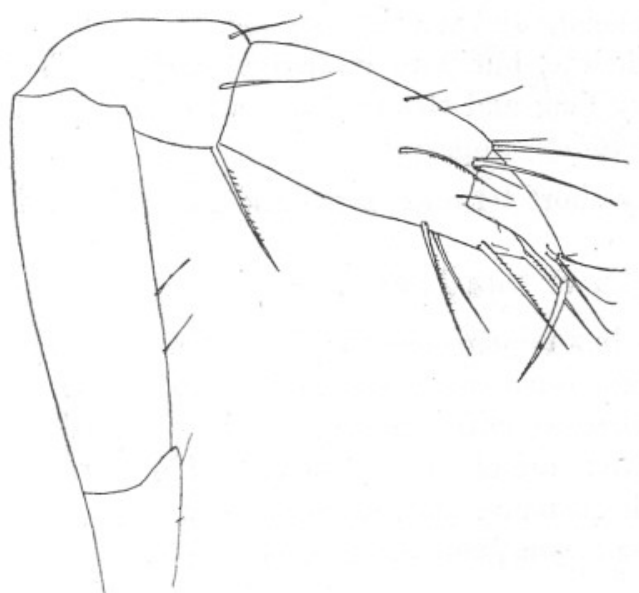

A.

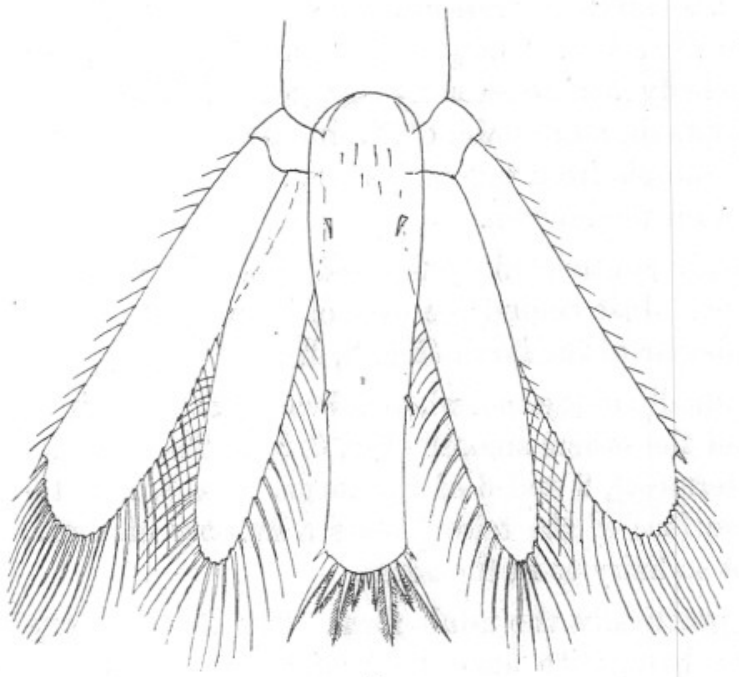

B.

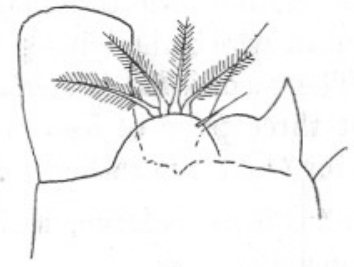

C.

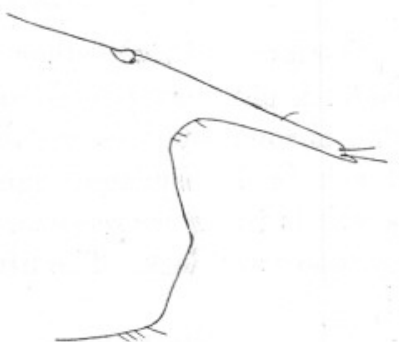

E.

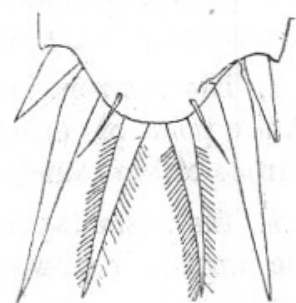

D.

Fig. 8.

A. Stage IX. First pereiopod of right side.

B. " ", Telson and uropods.

C. Ist post-larval stage. Antennular lobe.

D. , ",$\quad$ End of telson.

E. " " " $\quad$ Anterior part of carapace and rostrum, showing trace of "dorsal organ." 
left side, but chelate on the right (Fig. 8, A). The chela fully formed, but retaining the terminal spine of the larva. One individual has been seen in which the left leg was chelate and the right simple.

The second leg is slender, chelate, but with undivided carpus. The last three pairs of legs are very long and slender, carried horizontally, giving the larva rather a characteristic appearance.

10. Pleopods large, with very short terminal setæ, and first traces of retinacula.

\section{The Colour of the Larva.}

The larvæ at early stages are but faintly coloured, but in Stages VIII and IX chromatophores are numerous and the animal is conspicuous. The chromatophores usually have a central nucleus of opaque yellow (black in transmitted light) with orange-red branches. The general colour is therefore reddish, with glistening yellow points scattered over the body and legs. The fifth leg is conspicuously golden-yellow.

\section{First Post-larval Stage. Length 9 to $10 \mathrm{~mm}$.}

With the next moult the larva is transformed into the post-larval stage, differing little from the adult. The general form is, however, but little changed, though the body is more laterally compressed. The young shrimp now, no doubt, adopts the adult habit of life, but several specimens found in an old plankton sample from the Eddystone area indicate that it does not always remain on the bottom.

1. The rostrum is sharply constricted at the end, bearing four setæ at the point of constriction. Just behind the base of it can still be seen a trace of the rounded tubercle of the larva (Fig. 8, E).

2. The telson tapers gradually to the end, where it bears six stout spines, the inner pair ciliated and the others smooth (Fig. 8, D). These spines correspond to setæ 1 (outermost), 2 and 6 of the larva, Nos. 3, 4 and 5 being lost. The dorsal surface of the telson bears a number of short, scattered hairs, but is not so hairy as in the adult.

3. The antennæ have practically the adult form. The first antenna is much expanded at the base, with an outer rounded process corresponding to the stylocerite of other Caridea. The antennular lobe is conspicuous, with four modified setæ and one simple hair (Fig 8, C). The outer flagellum has a swollen basal part of five joints bearing æsthetes, and a slender terminal part of three joints.

4. The mandible has the general form of that of the adult. It seems to me that the usual description of this type of mandible as being one from which the cutting part has been lost is misleading. Rather it appears that both molar and cutting parts are present, but that the 
latter has, as it were, been folded over till it lies parallel to the molar portion, with a horseshoe-shaped depression between the two (Fig 9, C). The same appears to be the case in the Crangonidæ.

5. In the second maxilla the endopodite is a finger-shaped process, without lobes, and the setæ of the lobes of the protopodite are reduced. Four inner lobes are still traceable, but the second lobe of the coxopodite is very minute.

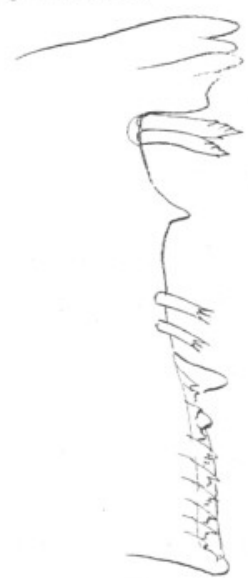

A.

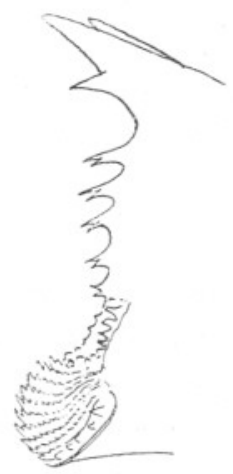

B.
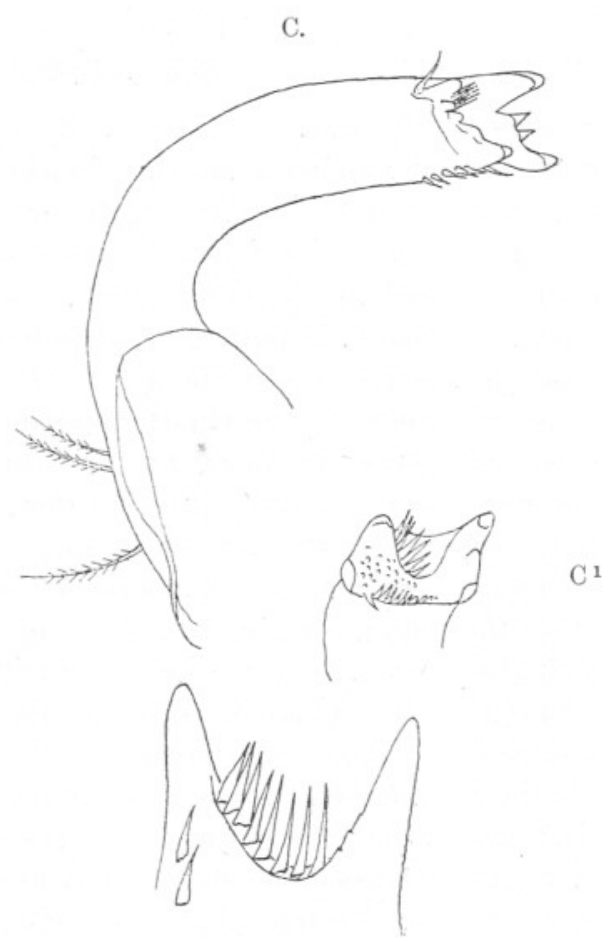

$C^{11}$.

1.

FIG. 9.

A. Mandible of larva in Stage V.

B. " ,,$\quad$ Stage IX.

C. " ",$\quad$ lst post-larval stage.

$\mathrm{C}^{1}$. The same. End view.

$\mathrm{C}^{11}$. , $\quad$ The end of the mandible seen from below.

6. The first maxillipede has a very large epipodite, but the basal joint on which it is borne seems to have lost its inner setiferous lobe.

The exopodite has now an expanded setiferous basal part, and the endopodite is reduced to an unjointed rod. 
7. The second maxillipede has also a large epipodite, and the endopodite has assumed the adult form.

8. The form of the legs is that of the adult, with the exception that vestiges of the exopodites are retained until the next moult, and the merus of the second pair is not divided. The carpus is divided into about thirteen joints.

9. The pleopods and uropods have the adult form, but the former show no sign of sexual differences.

\section{CONCLUSIONS.}

The genus Processa was included by Spence Bate in his tribe Polycarpinea, which also contained the Alpheidæ, Hippolytidæ and Pandalidæ, the characters common to all being the slenderness of the second pereiopod and the division of its carpus into several joints; but this grouping, though accepted by Stebbing (1893), has not been adopted by recent authors. Ortmann, in particular, abandoned any larger divisions among the Caridea, and arranged the genera in families, placing the Processidæ in close relation with the Gnathophyllidæ and Crangonidæ. The same course was followed by Boas, who also considered Processa and Crangon to be most nearly related to each other, but placed Hippolyte on the direct line of ancestry from which sprang these two genera on the one hand and Palæmon and Pontonia on the other (1888, p. 67). Borradaile, on the other hand, reverted to a grouping of the families into tribes, and united the Processidæ with the Crangonidæ and others into one group, the Crangonoida. There is, therefore, an agreement in each case in the assumption of a close connection between the Processidæ and Crangonidæ, while the Pandalidæ are rather widely separated from both.

Systematists have for the most part refused to attach much importance to the larval stages as evidence of relationship, Ortmann in particular (1896) expressly stating that embryology is of very small value in classifying Crustacea; but it seems to me that larval stages should, when known, be taken into account. The question of the degree of importance to be attached to them is, however, a difficult one which I am not prepared to deal with on this occasion, but I believe that in this particular case the larval development does throw some light on the systematic position of the genus Processa.

It must be admitted that the larvæ of the Caridea are so remarkably uniform in general structure that it is difficult to discover characters which are of real systematic importance, and the difficulty is greatly increased by the fact that our knowledge of these larvæ is still extremely limited. 
We know, for instance, the larval history of but one species (Hippolyte varians) among the Hippolytidæ, but the structure of certain larvæ assigned by Stephensen (1916) to the genus Spirontocaris shows that $H$. varians cannot be accepted as altogether typical of the family. Again, the very inadequate account of the larva of Pontonia given by Gourret (1884) indicates that the characters peculiar to the larvæ of Leander may be of generic rather than of higher importance, and it is difficult to distinguish among the generically different larvæ of the Crangonidæ characters which are common to all and distinctive of the family.

In the following table I have endeavoured to summarise the resemblances and differences between the larvæ of the four families in question, but I am well aware that the published information with regard to the Hippolytidæ is insufficient for a really satisfactory comparison.

The following conclusions seem to be justified by this table :-

1. The larvæ of the Pandalidæ and Processa agree in almost every detail of structure, and are, in fact, only separable with great difficulty.

2. In some respects these larvæ very closely resemble those of the Hippolytidæ, particularly those of Spirontocaris.

3. They differ in important respects from those of the Crangonidæ, while the Hippolytidæ resemble the Crangonidæ with regard to some of the features in which they differ from the Pandalidæ.

The larvæ of Pandalus and Processa, with their progressive development with scarcely any metamorphosis, and with their well-developed thoracic appendages with six or usually seven exopodites, are strikingly different from those of the Crangondiæ with their well-marked developmental stages and abrupt metamorphosis to the post-larval form. In the Crangonidæ the endopodites of the pereiopods are carried as unjointed functionless organs until the moult to the post-larval stage, as is the case with the Brachyura and Anomura. Not more than the first two pairs bear exopodites. Hippolyte varians resembles the Crangonidæ in the undifferentiated appearance of the endopodites of the pereiopods, and in the disappearance of the exopodites from the last three pairs; but in Spirontocaris, not only are the endopodites of these legs developed as in Pandalus (Stephensen), but there may be exopodites on all but the last pair. In Hippolyte there are five larval stages and considerable metamorphosis, but it is not known whether the same is true in Spirontocaris.

It seems, therefore, that the conclusions to be drawn from a study of these larvæ are not in accordance with the accepted view of the relationship of the adults, for they undoubtedly negative any grouping of the genus Processa with the Crangonidæ, and tend to support a reinstatement 


\begin{tabular}{|c|c|c|c|c|c|c|}
\hline & & & Crangonidæ. & Hippolytidæ. & Pandalidæ. & Processa. \\
\hline Larval Stages & . & . & $\begin{array}{l}\text { Five. Complete metamor- } \\
\text { phosis at 5th moult }\end{array}$ & $\begin{array}{l}\text { Five (Hippolyte). Metamor- } \\
\text { phosis less marked }\end{array}$ & $\begin{array}{l}\text { More than five. Develop- } \\
\text { ment gradual, metamor- } \\
\text { phosis very slight }\end{array}$ & As in Pandalus. \\
\hline Carapace & . & - & $\begin{array}{l}\text { Without dorsal or supra- } \\
\text { orbital spines. Anterior } \\
\text { ventral edge denticulate }\end{array}$ & $\begin{array}{l}\text { Supraocular spines small. } \\
\text { Median tubercle behind } \\
\text { rostrum. Anterior edge } \\
\text { denticulate }\end{array}$ & $\begin{array}{l}\text { Supraocular spines large. } \\
\text { Median tubercle behind } \\
\text { rostrum. Anterior edge } \\
\text { not denticulate }\end{array}$ & $\begin{array}{l}\text { Supraocular spines small. } \\
\text { Median tubercle behind } \\
\text { rostrum, Anterior edge } \\
\text { minutely denticulate or } \\
\text { smooth. }\end{array}$ \\
\hline Rostrum & . & . & Generally broad at base & $\begin{array}{l}\text { Short, slightly enlarged at } \\
\text { base }\end{array}$ & $\begin{array}{l}\text { Slender, not dilated at base. } \\
\text { With dorsal teeth in mysis } \\
\text { stage }\end{array}$ & Small, narrow \\
\hline Telson & . & . & $\begin{array}{l}\text { Remaining broad at end } \\
\text { till last stage. Posterior } \\
\text { edge nearly straight (ex- } \\
\text { cept in Pontophilus) }\end{array}$ & $\begin{array}{cc}\text { Becoming } & \text { narrow in last } \\
\text { stage. } & \text { Posterior edge } \\
\text { straight } & \text { (Hippolyte) }\end{array}$ & $\begin{array}{l}\text { Becoming narrow in last } \\
\text { stage. Posterior edge } \\
\text { deeply hollowed. }\end{array}$ & $\begin{array}{l}\text { Becoming narrow, Posterior } \\
\text { edge not deeply hollowed. }\end{array}$ \\
\hline \multicolumn{3}{|c|}{ Abdominal Segments } & $\begin{array}{l}\text { Fifth always with a pair of } \\
\text { spines. Third usually with } \\
\text { one or two dorsal spines }\end{array}$ & $\begin{array}{l}\text { A minute pair of spines on } \\
\text { 5th segment in Spiron. } \\
\text { tocaris? }\end{array}$ & $\begin{array}{l}\text { Spines entirely absent (Pan- } \\
\text { dalina). Sometimes pre- } \\
\text { sent in Pandalus }\end{array}$ & $\begin{array}{l}\text { A small pair of spines on } \\
\text { 5th segment. }\end{array}$ \\
\hline 1st Antenna & . & . & $\begin{array}{l}\text { Inner branch a straight, } \\
\text { spinous process. Stem } \\
\text { rather short and thick } \\
\text { (except Pontophilus) }\end{array}$ & $\begin{array}{l}\text { Inner branch represented by } \\
\text { a seta in lst stage. Stem } \\
\text { short and stout (Hippo- } \\
\text { lyte) }\end{array}$ & $\begin{array}{l}\text { Inner branch as in Hippo- } \\
\text { lyte. Stem long and } \\
\text { slender }\end{array}$ & $\begin{array}{l}\text { Inner branch as in Hippo- } \\
\text { lyte. Stem long, slender, } \\
\text { much curved. }\end{array}$ \\
\hline 1st Maxilla & . & . & $\begin{array}{l}\text { Basipodite without an outer } \\
\text { seta }\end{array}$ & Outer seta present & Outer seta absent & Outer seta present. \\
\hline Pereiopods & . & . & $\begin{array}{l}\text { Only one (Crangon) or two } \\
\text { (Philocheras) with ex- } \\
\text { opodite. All endopodites } \\
\text { functionless }\end{array}$ & $\begin{array}{l}\text { Only two with exopodite } \\
\text { (Hippolyte) or four (Spi- } \\
\text { rontocaris). Endopodites } \\
\text { functionless (Hippolyte) }\end{array}$ & $\begin{array}{l}\text { Three or four with ex- } \\
\text { opodites. Endopodites } \\
\text { functional }\end{array}$ & $\begin{array}{l}\text { Four exopodites. } \\
\text { podites functional. }\end{array}$ \\
\hline 2nd Antenna & . & . & $\begin{array}{l}\text { Scale not jointed at end in } \\
\text { early stages. Endopodite } \\
\text { a thick rod at first, swollen } \\
\text { at base }\end{array}$ & $\begin{array}{l}\text { Scale jointed at end. Endo- } \\
\text { podite a rod swollen at base } \\
\text { and with one terminal } \\
\text { spine or seta }\end{array}$ & $\begin{array}{l}\text { Scale jointed. Endopodite } \\
\text { at first a slender rod with } \\
\text { two setæ; never swollen } \\
\text { at base }\end{array}$ & $\begin{array}{l}\text { Scale not jointed, very } \\
\text { narrow. Endopodite as } \\
\text { in Hippolyte. }\end{array}$ \\
\hline 1st Maxillipede & & . & $\begin{array}{l}\text { Very small epipodite in } \\
\text { Stage V }\end{array}$ & Small epipodite & Epipodite large & Epipodite large. \\
\hline
\end{tabular}


of Spence Bate's tribe of Polycarpinea. From this tribe the Alpheidæ. must, however, be excluded, since they differ both in larval and in adult characters from the Hippolytidæ, Pandalidæ and Processidæ and approach the Palæmonidæ.

\section{LITERATURE CITED.}

BoAs, J. E. V. Studier over Decapodernes Slægtskabsforhold. Vid. Selsk. 'Skr. Ser. 6, 1880.

Borradaile, L. On the Classification of the Decapod Crustaceans. Ann. Mag. Nat. Hist. (7), XIX, 1907.

Czerniavsky, V. Crustacea Decapoda Pontica. Suppl. to Bd. 13. Trudui Obshchestva. Kharkov, 1884.

Gourret, P. Considerations sur la fauna pélagique du Golfe de Marseille. Ann. Mus. Hist. Nat. Marseille, II, 1884.

Jourdarn. Sur les changements de couleur de Nika edulis. Comptes Rendus, t. 87,1878 , p. 302.

Kemp, Stanley. The Decapoda natantia of the Coast of Ireland. Fisheries, Ireland Sci. Invest., 1908, I (1910).

Mortensen, Тн. Undersögelser over vor almindelige Rejes (Palcomon Fabricii). Vid. Undersögelser paa Fiskeriernes Omraade udgivne af Dansk Fiskeriforening, 1897.

Ortmann, A. Das System der Decapoden Krebse. Zool. Jahrb. Syst. IX, 1896, p. 409.

Risso, A. Histoire naturelle des Crustacés des environs de Nice, 1816.

SARs, G. O. Account of the Post-embryonal Development of Hippolyte varians. Arch. f. Math. og Naturvid. XXXII, 1912.

Account of the Post-embryonal Development of Pandalus borealis. Report on Norwegian Fishery and Marine Investigations, I, 1900, No. 3.

Sollaud, E. Sur une nouvelle varieté pœcilogenique du Palcmonetes varians. C. R. Acad. Sci., Paris, 155, 1912, p. 1268.

Stebbing, T. R. R. Crustacea. Intern. Scientific Series, LXXIV, 1893.

Stephensen, R. Zoogeographical Investigation of certain Fjords in Southern Greenland. Meddelser om Grönland, LIII, 1916.

Williamson, H. C. Decapoden. I teil (Larven). Nordisches Plankton. Lief. XVIII, 1915. 